\title{
28 Research Square \\ First serological evidence of West Nile virus among equines and birds in Kosovo, 2018-2019
}

\section{Agim Rexhepi}

University o Prishtina "Hasan Prishtina", Faculty of Agriculture and Veterinary

Kurtesh Sherifi ( $\nabla$ kurtesh.sherifi@uni-pr.edu )

University of Prishtina "Hasan Prishtina", Faculty of Agriculture and Veterinary

\section{Kristaq Berxholi}

Universiteti Bujqesor i Tiranes Fakulteti i Mjekesise Veterinare

\section{Betim Xhekaj}

University of Prishtina "Hasan Prishtina", Faculty of Agriculture and Veterinary

\section{Nesade Muja-Bajraktari}

Universitety of Prishtina "Hasan Prishtina", Faculty of Mathematics and Natural Sciences

\section{Aykut Özkul}

Ankara University, Faculty of Veterinary Medicine

\section{Ronald von Possel}

Bernhard-Nocht-Institut fur Tropenmedizin

\section{Petra Emmerich}

Bernhard-Nocht-Institut fur Tropenmedizin

\section{Short report}

Keywords: West Nile virus, Kosovo, Equines, Birds, Mosquitoes.

Posted Date: April 6th, 2020

DOI: https://doi.org/10.21203/rs.2.22635/v2

License: (c) (1) This work is licensed under a Creative Commons Attribution 4.0 International License. Read Full License

Version of Record: A version of this preprint was published at Vector-Borne and Zoonotic Diseases on February 1st, 2021. See the published version at https://doi.org/10.1089/vbz.2020.2673. 


\section{Abstract}

Background: This study was conducted to survey the presence of West Nile virus (WNV) in Kosovo by serological testing of apparently healthy local horses and attempts to detect viral nucleic acid in birds and mosquitoes. Methods: Between January 2018 and June 2019, 260 equine serum samples were collected, additionally 580 adult mosquitoes (53 pools) grouped in for genera, including Culex spp. (226 individuals; 26 pools), Aedes spp. (136 individuals; 16 pools), Anopheles spp . (184 individuals; 7 pools), Culiseta spp . (34 individuals; 4 pools). 50 domestic birds and 51 wild birds were collected from different regions of Kosovo. Equine and domestic bird serum samples were tested by flavivirus IgG ELISA while mosquitoes and bird viscera were tested for WNV RNA by RT-qPCR. All ELISA-positive results were confirmed by plaque reduction neutralization test (PRNT) and by virus neutralization test (VNT). Results: This is the first report providing evidence of WNV antibodies among animals in Kosovo. WNV antibodies were present in 27 out of 260 equine sera (10.38\%) and one out of 50 samples in domestic birds by ELISA and PRNT. Eight of 27 positive equine serum samples with high titer neutralized WNV, but not USUV. No WNV RNA was detected in birds or mosquitoes. Conclusions: The occurrence of WNV antibodies in local equines from all regions of Kosovo indicates that the virus is circulating within the country. Public health authorities should therefore plan a risk assessment and disease control program. Keywords: West Nile virus, Kosovo, Equines, Birds, Mosquitoes.

\section{Background}

West Nile virus (WNV) is an arthropod-borne virus of the Flaviviridae family with worldwide distribution [1]. In Europe are 4,700 West Nile fever (WNF) recorded from 2011-2019, with the highest number of 1,503 registered in the year 2018 [2]. Since 1999 WNF has caused over 37,000 reported cases in North America. However, in many parts of African countries has been detected WNV, which initially was spread from there to other continents [3,4]. The natural cycle of infection involves many species of birds and mosquitoes. In Europe, these are predominantly mosquitoes from the genus Culex, whereas $C x$. pipiens is considered to be the most important vector for WNV [5]. Birds are the natural reservoir of the virus, serving as amplifying hosts, while humans and horses are considered accidental or dead-end hosts [6].WNV infection is often asymptomatic in humans and equines, with approximately $20 \%$ of human cases showing febrile syndrome and neuroinvasive disease in less than $1 \%$ of patients [7].

While up to 9 genetic lineages of WNV have been identified, lineage 1 and 2 are both circulating in Europe and appear to have significant medical importance [8]. Over the past 50 years the lineage 1 has been responsible for the occurrence of diseases in Mediterranean basin, since 1999 was introduced into North America. WNV lineage 2 was first isolated in Hungary in 2004, however further spread in neighboring countries has been recorded, which in the year 2010 and 2011 cause an outbreak in Greece, respectively Italy $[9,10]$. Recent studies report that lineage 2 of WNV is endemic in Europe, including Balkan countries $[10,11,12]$. Furthermore, West Nile fever (WNF) outbreaks have caused great concern for Europe's public health authorities $[13,14]$. 
In Albania, WNV antibodies in humans were first detected in Europe in 1958 [15], while in recent years in this country only two human cases were recorded in 2011 [2]. Since 2008, WNV from humans, equines, birds, and mosquitoes has been detected or isolated in many European countries. In Serbia the first outbreak of human WNF was reported in 2012 with 69 reported and 41 clinically and laboratory confirmed cases, which in the next year's seasonal outbreaks were occurred. Also, in Greece the first large outbreak of WNF was reported in 2010 with 262 infected people and up to year 2019 seasonal outbreak were registered, whereas together with Italy and Serbia comprise the most affected countries in Europe [2, $16,17]$.

WNF cases in Kosovo were first reported in 2012, with four patients being confirmed clinically and in the laboratory. Between 2013 and 2015, 14 infected people were identified [18]. The latest outbreak of WNF in Kosovo was in 2018, with 14 human cases, including three deaths [2].

Data about WNV infection in animals and mosquitoes is lacking in Kosovo. In the first study carried out in the country in 2010, 29 equine serum samples were serologically tested and no WNV antibodies were found [19]. In the same study a seroprevalence rate of $22 \%$ in horses in neighboring Albania was detected, although no antibodies found in birds [19]. Globally, WNV has been detected in more than 300 bird species, while viral nucleic acid has been detected in 75 species of mosquitoes [20]. Culex pipiens has been found to be the most widespread species of mosquitoes in Kosovo, representing around $40 \%$ of the distribution of 13 identified species in the country [21]. No WNV infections have been documented in animals in Kosovo, yet.

The aim of this study was to investigate the presence of WNV in horses, mosquitoes, and birds in Kosovo.

\section{Material And Methods}

\section{Sampling}

Equine sera: 260 equine blood samples (251 horses, 7 donkeys, and 2 mules; mean age $=10.9$ years, range $=1-32$ years) were collected from seven regions of Kosovo between January and September 2018: Prishtina $n=32$, Mitrovica $n=28$, Peja $n=25$, Prizren $n=47$, Gjakova $n=12$, Ferizaj $n=50$, and Gjilan, $n=66$. The samples originated from 177 different animal owners. There are 2,353 equines in Kosovo [22]. Blood samples were collected randomly from healthy horses with no history of West Nile neuroinvasive diseases (WNND) in animals. . Sera were kept at $-20^{\circ} \mathrm{C}$ until use.

Bird sampling: 50 sera of domestic birds (backyard chickens) were collected between June-October 2019 . The chickens aged from 1 to 3 years old, were purchased from free-range farms and kept outdoors. After slaughtering, $5 \mathrm{ml}$ blood was collected from each animal while $5 \mathrm{~g}$ of viscera tissues from the brain, liver, heart, kidney, and lungs were pooled and stored in $-80^{\circ} \mathrm{C}$ freezer. In addition, 51 wild bird samples from the Corvidae family were collected randomly, such a Hooded Crown (Corvus corone) 2 samples, Jackdaw (Corvus monedula) 9 samples and Raven (Corvus corax) 40 samples, as they found dead by hunters and 
stored in $-20^{\circ} \mathrm{C}$ freezer. The birds' viscera (brain, liver, heart, kidney, and lungs) were pooled and stored at $-80^{\circ} \mathrm{C}$.

Mosquito sampling: Mosquito samples were collected in the period from June-October 2019, from the same farms of the equine samples. Collections were made using an Insect Monitoring Trap (IMT "Genicco SRL", Italy) with dry ice. The traps were in place overnight. After the morphological identification of mosquitoes on the same day of collection, specimens were stored immediately in a $-20^{\circ} \mathrm{C}$ for one week and after that in a $-80^{\circ} \mathrm{C}$. Before RT-PCR screening, all mosquitoes were pooled from 5 to 30 individuals, depending on its genera and collection sites. The 580 mosquitoes, adult females (53 pools) were grouped in for genera, including Culex spp. (226 individuals; 26 pools), Aedes spp. (136 individuals; 16 pools), Anopheles spp. (184 individuals; 7 pools), Culiseta spp. (34 individuals; 4 pools). The sampling period coincided with the peak activity period for these mosquito species. Adult specimens were morphologically identified under binocular stereomicroscope (Motic, SMZ-161, Hong Kong) to genus level based on main morphological characteristics using interactive identification keys for mosquitoes of the Euro-Mediterranean Region [23].

\section{Serological Testing}

ELISA (Enzyme-linked immunosorbent assay): Sera were tested for WNV-reactive antibodies using a commercially available ELISA-blocking enzyme immunoassay, which allowed recognition of WNV-IgGantibodies (INGEZIM west Nile COMPAC, Madrid, Spain). ELISA was performed according to the manufacturer's instructions.

PRNT (plaque reduction neutralization test): All ELISA-positive serum samples were then subjected to PRNT to confirm the presence of virus specific antibodies. The test was performed on two-fold dilutions of the serum samples (starting from 1:20) against a $100 \mathrm{pfu} / 100 \mathrm{~mL}$ diluted NY99 (lineage 1) strain of the WNV on Vero cells (ATCC CCL81). Serum samples blocking $90 \%$ of plaque occurrence were considered positive for WNV-specific antibodies.

VNT (virus neutralization test): eight ELISA and PRNT positive horse sera were then confirmed by virus neutralization test (VNT), with neutralizing antibody titers from 1:320 to 1:1,280, using WNV strain NY99 and USUV strain 1477 on Vero E6 cells [24].

\section{RT-qPCR Testing}

RNA extraction from mosquito and bird organs: the mosquito pools (5-30 individuals) and $0.5 \mathrm{~g}$ of bird organ ( $0.1 \mathrm{~g}$ of brain, lung, heart, kidney, and lungs) were placed in a $2 \mathrm{ml}$ Eppendorf tube containing three to five steel beads ( $7 \mathrm{~mm}$, Qiagen, Hilden, Germany), frozen on liquid nitrogen and directly pulverized in a Tissue-Lyser LT (Qiagen, Hilden, Germany) with a $-20^{\circ} \mathrm{C}$ pre-cooled rotor at $50 \mathrm{~Hz}$ for $2-5$ min. Repeated freezing and lysis was necessary in some cases. The samples were then re-suspended in 300-500 $\mu \mathrm{l} \mathrm{PBS} \mathrm{(depending} \mathrm{on} \mathrm{tissue} \mathrm{size)} \mathrm{containing} 500 \mathrm{IU} / \mathrm{ml}$ penicillin, $10 \%$ fetal calf serum, and 500 
$\mu \mathrm{g} / \mathrm{ml}$ amphotericin, and centrifuged at 2,000 $\times \mathrm{g}$. Viral RNA extraction was done with QIAamp ${ }^{\circledR}$ Viral RNA Mini Kit (Qiagen, Hilden, Germany) according to the manufacturer's instructions.

RT-qPCR: $25 \mu$ l RNA of each sample extractions were tested using RealStar ${ }^{\circledR}$ WNV RT-PCR Kit 1.0, (Altona Diagnostics, Hamburg, Germany) for the detection of West Nile virus (WNV) RNA, according to the manufacturer's instructions.

\section{Results}

Of the 260 equine serum samples, $10.38 \%$ (27 out of 260 ) reacted in the antibody-ELISA of WNV. These samples were further tested for neutralizing antibodies using PRNT with titers ranging from 1:20 to 1:80. Samples testing positive from both the ELISA and PRNT were considered as positive for WNV-specific antibodies. Eight of 27 high titer samples, neutralized WNV, but not USUV by VNT.

The results revealed that WNV-seropositive horses are widespread in Kosovo. WNV antibodies were detected in horses from seven regions with different seroprevalence rates. The highest rate was in Peja $20.00 \%$ (5/25), followed by Mitrovica 17.86\% (5/28), Gjakove 16.67\% (2/12), Ferizaj 10\% (5/50), Gjilan $9.09 \%$ (6/66), Prizren 6.38\% (3/47), and Prishtina 3.13\% (1/32). No positive samples were detected from donkeys or mules.

One domestic bird (2\%) resulted positive for WNV antibodies out of 50 chickens tested, near to Kosovo's capital city, Prishtina (Table 1).

The most abundant mosquito genera trapped close to WNV-positive locations for equines was Culex spp. (in 21 out of 27 locations), representing $36 \%$ of all mosquito genera . In contrast, no vRNA was detected by RT-qPCR (Figure 1).

None of the 51 wild birds or 50 domestic birds was positive for viral RNA by RT-qPCR.

\section{Discussion}

This study provides the first report of WNV seropositivity in equines and birds in Kosovo. The wide distribution of WNV antibodies in local equines from all regions of Kosovo indicates that the virus is already circulating within the country. A study in Kosovo from 2010 detected no antibody response to WNV infection in serum samples collected from 29 horses [19]. However, this was most likely due to the small sample size.

Surveys from neighboring countries have detected the following WNV infection rates in healthy equines: Croatia $0.41 \%$ (2007), Serbia $12 \%(2009 / 10)$, and Albania $22 \%(2010)[19,25,26]$. In a study realized in northern Serbia in the year 2007-2011 with 252 equine serum samples was found a seropositivity by $28.6 \%$ [27]. 
WNV appears to have been introduced into Kosovo between 2008 and 2012, with the first reported human cases in 2012, when four patients were confirmed by laboratory tests [18].

Kosovo's most abundant mosquito species is Culex pipiens of the 13 identified species in the country [21]. In our study, too, the most frequent species was Culex spp. (36\%), which appeared in 21 out of 27 sampled locations (78\%) where equines tested positive for WNV antibodies, as we have collected equine sera samples and mosquitoes from 177 farms. Our survey did not detect viral genomic RNA by RT-qPCR, perhaps due to the small sample size for mosquitoes and birds.

Further surveillance studies in vectors and animals are thus necessary to determine the WNV linages that circulated among birds and mosquitoes to assess the risk for humans and animals.

\section{Conclusions}

This report provides the first evidence of WNV antibodies among local equines and birds in Kosovo. The most predominant mosquito genus in the country sampled near equine farms was Culex spp... The occurrence of WNV in Kosovo is a serious concern for public health authorities in planning their strategies for disease prevention and control.

\section{Abbreviations}

ELISA-Enzyme linked immunosorbent assay; PRNT: Plaque reduction neutralization test; VNT: Virus neutralization test; RNA: Ribonucleic acid; RT-PCR: Reverse transcriptase polymerase chain reaction; WNV: West Nile virus; WNF: West Nile fever; WNND: West Nile neuroinvasive diseases

\section{Declarations}

\section{Acknowledgments}

The authors are grateful to local Kosovan Veterinarian Veton Haziri and Dr. Sabri Hacioglu from the Ankara University.

\section{Funding}

This work was supported by a grant from the Ministry of Education, Science and Technology of Kosovo (Project No. 2-3970-2).

\section{Availability of data and materials}

Not applicable.

\section{Author Contributions}

A.R., K.SH, B.X., K.B., and N.M-B. collected samples in the field. 
K.SH., B.X., P.E., R.P., K.B., and A.O. performed laboratory analyses and interpreted the results.

A.R., K.SH., coordinated the study and drafted the manuscript.

All authors reviewed and approved the final version of the manuscript.

\section{Ethics declarations}

\section{Ethics approval and consent to participate}

Not applicable.

\section{Consent for publication}

Not applicable.

\section{Competing interests}

The authors declare that they have no competing interests.

\section{References}

1. 1. Calistri P, Giovannini A, Hubalek Z, lonescu A, Monaco F, Savini G, et al. Epidemiology of West Nile in Europe and in the Mediterranean basin. Open Virol J. 2010;4:29-37.

2. European Center for Disease Prevention and Control. Historical Data by Year-West Nile Fever Seasonal Surveillance. Accessed on 20 February 2020. Available online:https://www.ecdc.europa.eu/en/west-nile-fever/surveillance-and-disease-data/historical

3. Roehrig JT. West Nile Virus in the United States - A Historical Perspective. Viruses 2013;5: 30883108.

4. Sule WF, Oluwayelu DO, Hernandez-Triana LM, Fooks AR, Venter M, Johnson N. Epidemiology and ecology of West Nile virus in sub- Saharan Africa. Parasit Vectors 2018; 11:414.

5. Vogels CB, Göertz GP, Pijlman GP, Koenraadt JM. Vector competence of European mosquitoes for West Nile virus. Emerg Microbes Infect. 2017:6, e96.

6. Komar N. West Nile viral encephalitis. Rev Sci. Tech. 2000;19:166-76.

7. Campbell GL, Marfin AA, Lanciotti RS, Gubler DJ. West Nile virus. Lancet 2002;2:519-529.

8. Pachler K, Lebl K, Berer D, Rudolf I, Hubalek Z, Nowotny N. Putative West Nile Virus Lineage in Uranotenia unguicuata Mosquitoes, Austria, 2013. Emerg Infect Dis. 2014 Dec;20(12)2119-22.

9. Hernández-Triana LM, Jeffries CL, MansfieldKL, Carnell G, FooksAR, JohnsonN. Emergence of West Nile virus lineage 2 in Europe: a review on the introduction and spread of a mosquito-borne disease. Front Public Health. 2014;2:271.

10. Magurano F, RemoliME, Baggieri M, FortunaC, MarchiA, FiorentiniC et al. Circulation of West Nile virus lineage 1 and 2 during an outbreak in Italy. Clin Microbiol Infect. 2012;18:545-547. 
11. Papa A, Bakonyi T, Xanthopoulou K,Vazquez A, Tenorio T, Nowotny N. Genetic characterization of West Nile virus lineage 2, Greece, 2010. Emerg Infect Dis. 2011;17:920-922.

12. Bakonyi T, Ferenczi E, Erdélyi K, Kutasi O, Csörgo T, Seidel B, et al. Explosive spread of a neuroinvasive lineage 2 West Nile virus in Central Europe, 2008/2009. Vet Microbiol. 2013;165 (12):61-70.

13. Haussig JM, Young JJ, Gossner CM, Mezei E, Bella A, Sirbu A, et al. Early start of the West Nile fever transmission season 2018 in Europe. Euro Surveill.2018; 23(32):pii=1800428.

14. European Centre of Disease Prevention and Control. Epidemiological Update: West Nile Virus Transmission Season in Europe. 2018.https://ecdc.europa.eu/en/news-events/epidemiologicalupdatewest-nile-virus-transmission-season-europe-2018. Accessed 18 October 2019.

15. Bardos V, Adamcova J, Dedei S, Gjini N, Rosicky B, Simkova A. Neutralizing antibodies against some neurotropic viruses determined in human sera in Albania. J Hyg Epidemiol Microbiol Immunol. 1959;3:277-282.

16. Popovic N, Milosevic B, Urosevic A, Poluga J, Popovic N, Stevanovic G, et al. Clinical characteristics and functional outcome of patients with West Nile neuroinvasive disease in Serbia. J Neurol. 2014;261:1104-11.

17. Papa A, Danis K, Baka A, Bakas A, Dougas G, Lytras T, et al. Ongoing outbreak of West Nile virus infections in humans in Greece, July-August 2010. Euro Surveill. 2010;15:19644.

18. Dreshaj S, Jakupi X, Sherifi K, Gjikolli B, Hasani N, ShalaN, et al. Human West Nile virus infection in Kosovo 2012-2015: A cross-sectional analysis. 13th World Conference on Neurology and Neuromuscular Disorders 2018,0ctober 01-02, Frankfurt, Germany.

19. Berxholi K, Ziegler U, Rexhepi A, Schmidt K, Mertens M, Korro K, et al. Indigenous West Nile Virus Infections in Horses in Albania. Transbound Emerg Dis. 2013;60(2):45-50.

20. Medlock JM, Snow KR, Leach S. Potential transmission of West Nile virus in the British Isles: an ecological review of candidate mosquito bridge vectors. Med Vet Entomol.2005;19(1):2-21.

21. Muja-Bajraktari N, Zhushi-Etemi F, Dikolli-Velo E, Kadriaj P, Gunay F. The composition, diversity, and distribution of mosquito fauna (Diptera: Culicidae) in Kosovo. J Vector Ecol. 2019;44 (1):94-104.

22. Report of Kosovo Agency of Statistics 2017. In Albanian language. http://ask.rksgov.net/media/4143/anketa-e-ekonomive-bujq\%C3\%ABsore-2017-shqip.pdf. Accessed 20 October 2019.

23. Gunay F, Picard M, Robert V. 2017. MosKeyTool, an interactive identification key for mosquitoes of Euro-Mediterranean. Version 1.1. http://medilabsecure.com/moskeytool. Accessed 20 October 2019.

24. Gabriel M, Emmerich P, Frank C, Fiedler M, Rashidi-Alavijeh J, Jochum C, et al. Increase in West Nile virus infections imported to Germany in 2012. J ClinVirol. 2013 Nov; 58(3):587-9.

25. Madic J, Savini G, Di Gennaro A, Monaco F, Jukić B, Kovac S, et al. Serological evidence for West Nile virus infection in horses in Croatia. Vet Rec. 2007;160(22):772-3. 
26. Lupulović D, Martin-Acebes M, Lazić S, Alonso-Padilla J, Blaquez A-B,Escribano-Romero E, et al. First Serological Evidence of West Nile Virus Activity in Horses in Serbia. Vector Borne Zoonotic Dis. 2011,11(9):1303-05.

27. Medić $S$, van den Hoven R, Petrović T, Lupulović $D$. Serological evidence of West Nile virus infection in the horse population in northern Serbia. J Infect Dev Ctries. 2014 Jul 14;8(7):914-8.

\section{Table 1}

\begin{tabular}{|c|c|c|c|c|c|c|c|c|c|c|c|}
\hline \multirow[t]{2}{*}{ Region } & \multicolumn{4}{|c|}{ Equines } & \multicolumn{3}{|c|}{ Domestic birds } & \multicolumn{2}{|c|}{ Mosquitos } & \multicolumn{2}{|c|}{ Wild Birds } \\
\hline & $\begin{array}{c}\text { No. } \\
\text { Tested }\end{array}$ & $\begin{array}{c}\text { ELISA } \\
\text { Positive }\end{array}$ & PRNT & VNT* & $\begin{array}{c}\text { No. } \\
\text { Tested }\end{array}$ & $\begin{array}{c}\text { ELISA } \\
\text { Positive }\end{array}$ & PRNT & $\begin{array}{c}\text { No. } \\
\text { pools } \\
\text { Tested }\end{array}$ & $\begin{array}{l}\text { RT-PCR } \\
\text { Positive }\end{array}$ & $\begin{array}{c}\text { No. } \\
\text { Tested }\end{array}$ & $\begin{array}{l}\text { RT-PCR } \\
\text { Positive }\end{array}$ \\
\hline Mitrovice & 28 & 5 & 5 & 2 & 0 & 0 & 0 & 1 & 0 & 0 & 0 \\
\hline Gjilan & 66 & 6 & 6 & 1 & 8 & 0 & 0 & 6 & 0 & 0 & 0 \\
\hline Ferizaj & 50 & 5 & 5 & 1 & 3 & 0 & 0 & 12 & 0 & 0 & 0 \\
\hline Gjakove & 12 & 2 & 2 & 2 & 3 & 0 & 0 & 6 & 0 & 0 & 0 \\
\hline Prizren & 47 & 3 & 3 & 1 & 8 & 0 & 0 & 7 & 0 & 0 & 0 \\
\hline Peje & 25 & 5 & 5 & 1 & 12 & 0 & 0 & 10 & 0 & 0 & 0 \\
\hline Prishtine & 32 & 1 & 1 & - & 16 & 1 & 1 & 11 & 0 & 51 & 0 \\
\hline $\begin{array}{l}\text { Total } \\
\text { No. }\end{array}$ & 260 & 27 & 27 & 8 & 50 & 1 & 1 & 53 & 0 & 51 & 0 \\
\hline Total \% & & $10.38 \%$ & $10.38 \%$ & & & $2.00 \%$ & & & $0 \%$ & & $0 \%$ \\
\hline
\end{tabular}

Table 1. Results for WNV in equines, birds, and mosquitoes in Kosovo. VNT* - Eight of 27 high titer samples, neutralized WNV, but not USUV.

\section{Figures}




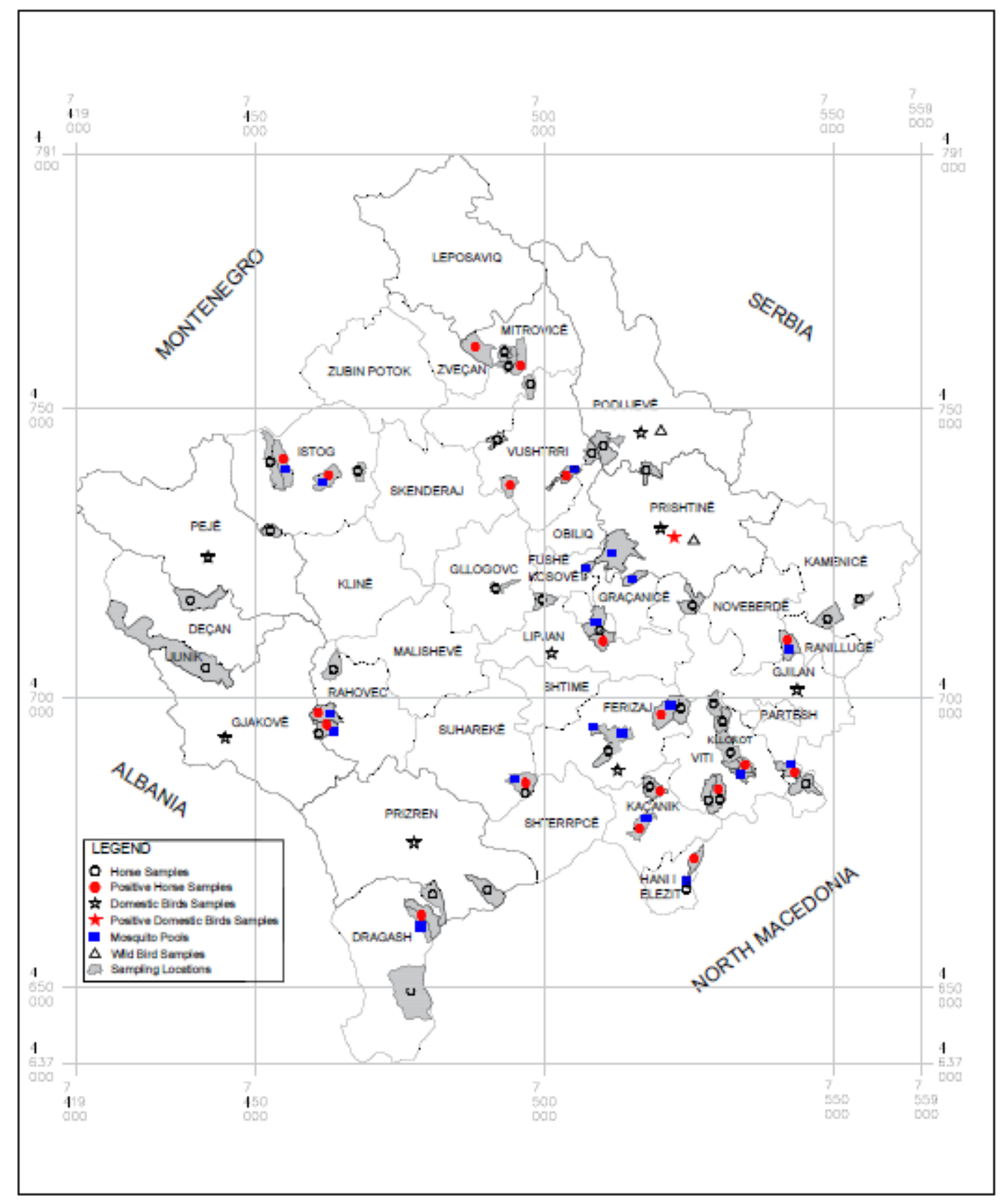

Figure 1

Geographical serosurveillance of equines and birds for WNV, and mosquito samlping, showing approximate locations of sampling locations in each village within Kosovo regions.

\section{Supplementary Files}

This is a list of supplementary files associated with this preprint. Click to download.

- GraphicalAbstract26.03.2020.jpg 